\title{
Specifics of the Economic Crisis in Russia
}

\author{
Sergey Alexandrovich Surkov ${ }^{1}$ \\ ${ }^{1}$ International Institute of Management LINK, Moscow region, 140180, Russian Federation \\ Correspondence: Sergey Alexandrovich Surkov, International Institute of Management LINK, Moscow region, \\ 140180, Russian Federation
}

Received: November 16, 2013

Accepted: March 5, $2014 \quad$ Online Published: March 7, 2014

doi:10.5430/rwe.v5n1p106

URL: http://dx.doi.org/10.5430/rwe.v5n1p106

\begin{abstract}
The article presents features of the growing crisis process in the Russian economy and allocated symptoms of approximation a crisis in the economy. The following three factors considered as grounds for such conclusions. In particular, it was observed the slowdown of GDP, an increase with years the difference between GDP and the sum of the GRP of Russian regions. In addition, the growth of human potential has practically ceased. Collection of data by the most significant and well-informed literary sources was used. Survey of experts was conducted by importance of the factors in the list of thirty-five indicators. These data were used to extract the most influencing factors and assessment of their significance. The result revealed that corruption, inefficient public administration, crisis of the education system and monopolization of the economy turned a most important for inhibition the development the Russian economy.
\end{abstract}

Keywords: crisis phenomena, crisis reasons, human development indicators

\section{Introduction}

Globalized world economy is undergoing a financial and another shock. Russia is part of the global economy as a producer of resources and consumer of industrial products. Crisis may be not very noticeable in Russia, whose economy and society as a whole are experiencing a systemic crisis. In this case, they will be to have a character of normal economic development permanent disruption. The Russian authority takes that into consideration. They enjoy the favorable situation to claim their political assessments of the real state the Russian economy.

\section{Literature Review}

President Vladimir Putin said that Russia does not expect serious economic shocks, but is ready to respond to the European economic crisis (Zubchenko, E., 2012). However, the difficulty lies in the fact that in 2008 there was a crisis of the modern economic model. This is indicated by Nikolaev I.A. (Zubchenko, E., 2012). Nikolaev I.A. calls it speculative model when investing in various assets for resale is becoming more predominant as compared to investments in fixed assets. The Russian economy, according to experts, is not so cut off from the world economy to not be at risk from the consequences of the crisis.

Mironov V., referring to forecast "Development Center" HSE, says that Russia's GDP growth in 2013 most likely will not exceed 2 percent.Net capital outflow is constantly growing. This means that Russian citizens and businesses prefer not to invest in the domestic economy. Central Bank reported that in 2011 from the country was removed out 84.2 billion dollars. Gutorova M. quoted the director of the Institute for Economic Research Bruegel (Brussels), Jean Pisani-Ferry. He believes that the impact of the global crisis on the Russian economy yet is not very obvious, and here takes place a sort of deferred impact.

\section{Methods}

As a method of research used the study of sources of data on GDP and other macroeconomic data. The results were compared with each other. Also conducted surveys of 132 managers, who is training for an MBA.

\section{Results}

We can construct a graph of the Russian GDP by years based on the information of the source with the additional data from other sources, for example, Russia completed 2011 with a budget surplus in 416,500,000,000,000. rubles. and Press agency FCO. Over the decade, growth of Russia's GDP was 159.2\% - calculation of the FCO. This plot is shown on Figure 1. 


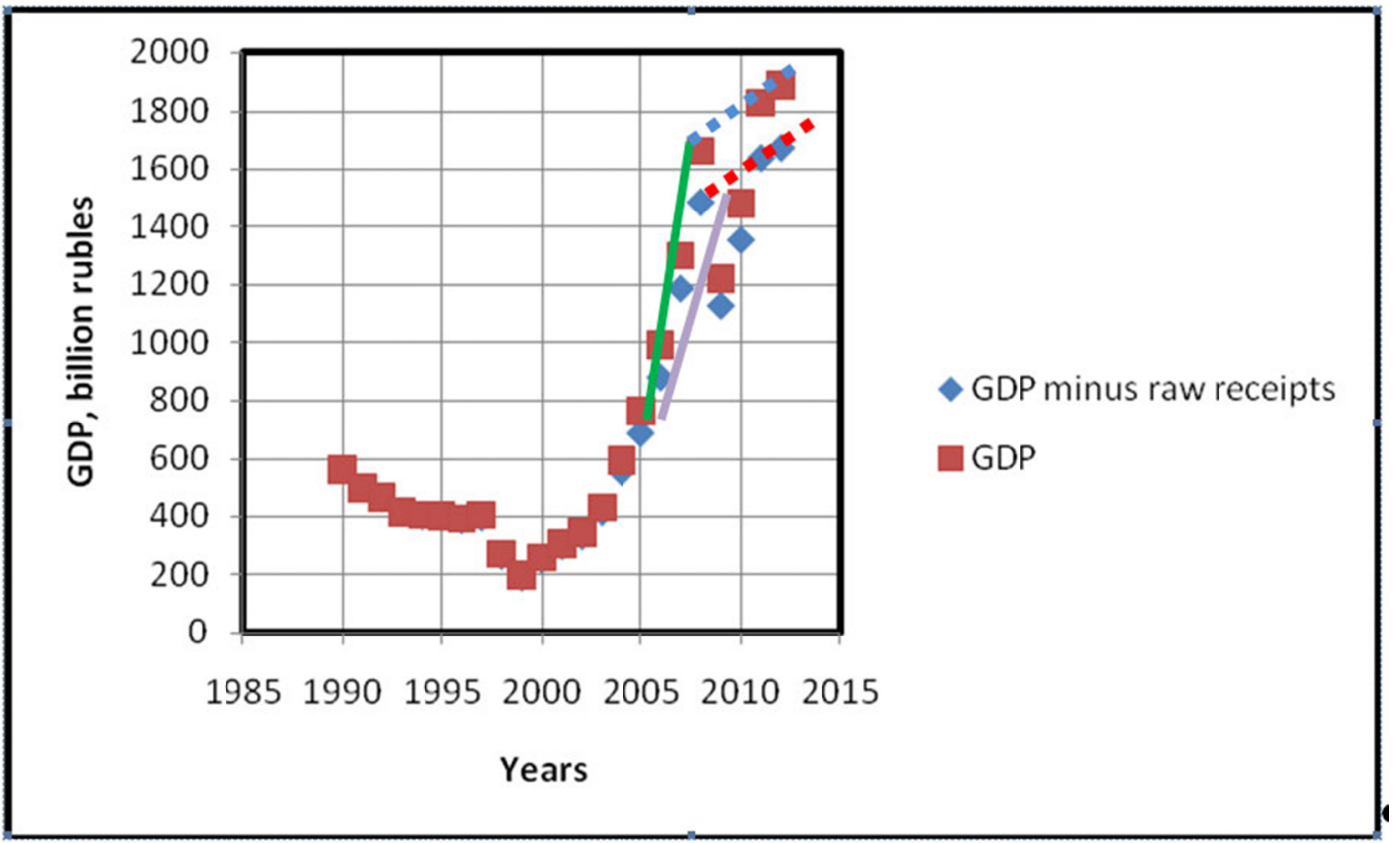

Figure 1. Change of GDP of Russia by years

The green line shown the linearization of the chart the change in GDP, the purple line shown the linearization of the chart the change in GDP, net oil and gas revenues. The dashed lines present the direct linearization of the decline in the growth rate of GDP for the last few years.

The graph in Fig.1 shows that Russia's GDP growth began after a period of decline since 2000. This growth continued until 2006-2007, with almost the same rate. Then growth rates started to fall. Apparently, this is the evidence of stagnation and a possible harbinger of the crisis.

As can be seen from Figure 2 graphs, official Rosstat data does not show this trend in the last years. However, for example, the computations Portnov A.M. give other estimate for the proportion of the raw materials production in Russia's GDP.

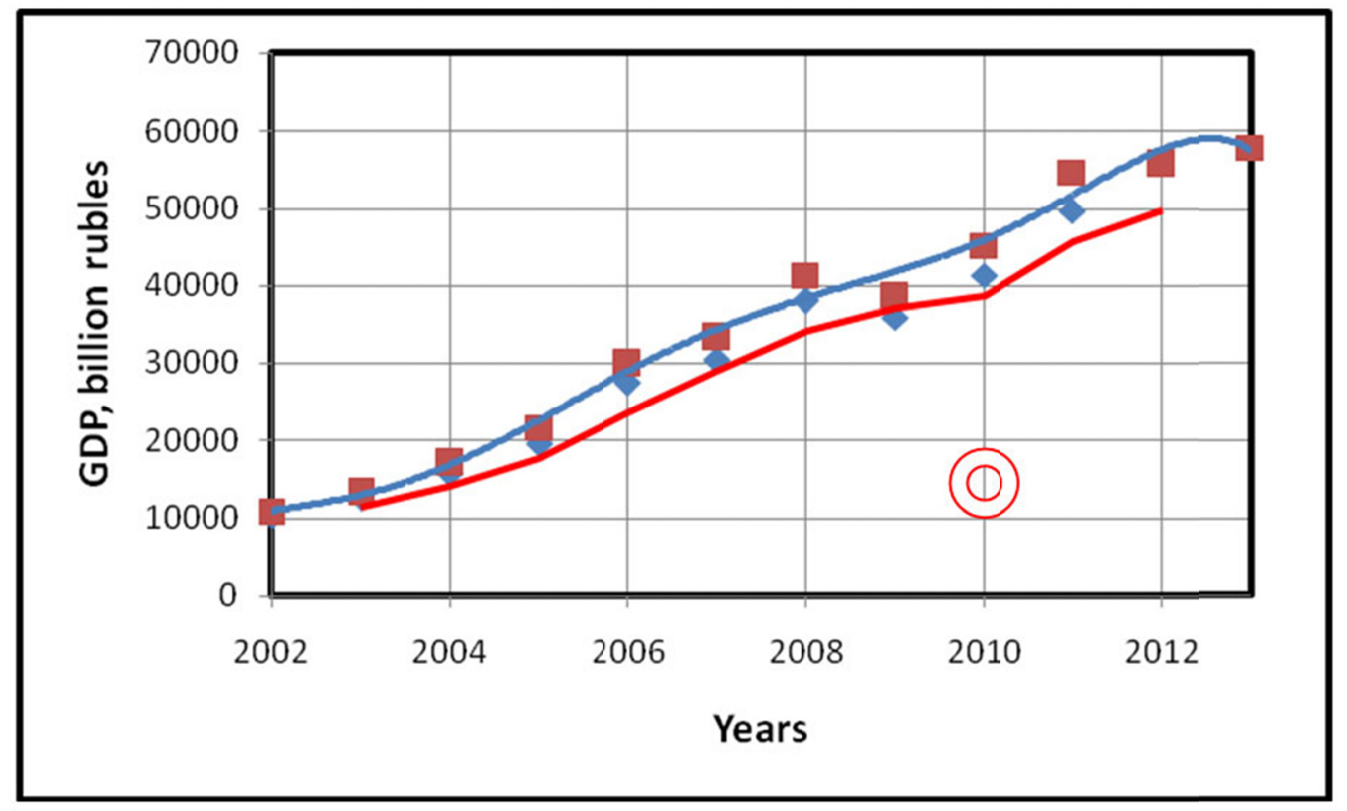

Figure 2. The change of Russia's GDP by years over the last decade. The upper dots row corresponds to GDP, the lower - GDP less the income from mining 
If we use his calculations for 2010, we can see a different result. Namely, a significantly higher share of extraction, by the words Portnov A.M., of a "simple product". Real level of GDP after subtracting the contribution of production of raw materials is shown in Figure 2 with the help of double circle. This is an additional certificate, that in the Russian economy negative trends slowdown of the growth rates were outlined. But from the main graph this is seen not enough clearly. More clearly the slowdown of the growth rates seen on entire considered interval of the time. The final plot is characterized by elevated rate of economic growth. But forecasts assume their decline, and accordingly the beginning of the crisis phenomena in economy.

Further analysis of trends in the Russian economy can be made by comparing GDP and the sum GRP Russian regions. Here there are own particulars. Glukhova M.V. indicates that the methodology for calculating GRP differs from methodology of calculating GDP.A series of components, which are included in the calculation of GDP, in the calculation of the GRP are not counted. Therefore, the total GRP of all Russian regions smaller GDP. These components include such as value added industries providing collective non-market services to society as a whole. In addition, this index includes value added of services to financial intermediaries, value added of foreign trade and part of the taxes, primarily, on imports and exports.

A comparison of GDP with the sum of GRP Russian regions, based on the data source (Website of the Federal State Statistics Service. http://www.gks.ru/), is presented in Figure 3a.
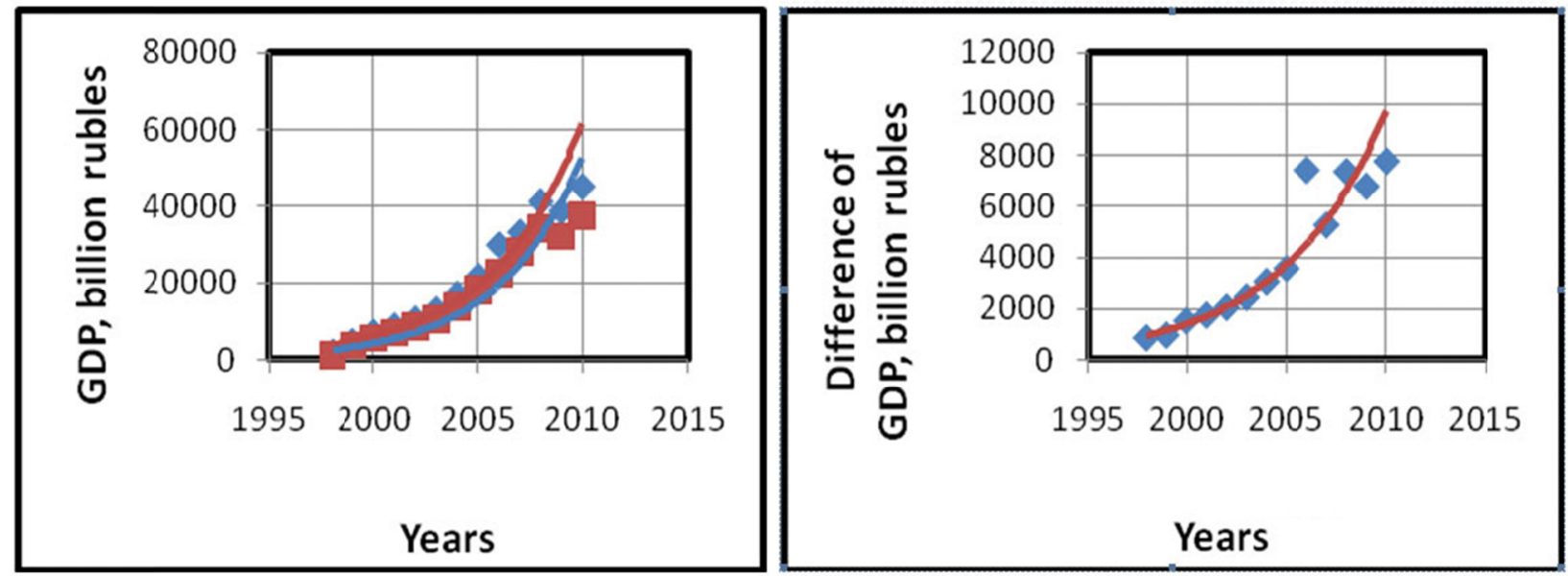

Figure 3. The Indicators of total national and regional products:

3a. Comparison of GDP and GRP sum by years and 3b. Dependence of a difference between GDP and the sum of regions GRP by years

From the graphs in Figure 3 can see that their character is similar. But the difference between them increases with time. If highlight their difference, as in Figure 3b, then acceleration in growth of the difference between GDP and of the sum GRP for the regions is clearly seen. Statistical agencies do not particularize the nature and components of this divergence. We can assume that the growth of government spending gives the main contribution. These costs, especially in anticipation of the transition to a post-industrial economy, cannot be considered productive. Anyhow, there is an increase of the aforementioned gap between GDP and the sum of the GRP. This increase points to the strengthening of structural problems, which does not contribute to out of the crisis.

The reasons of formation the Russian version of the approach to the crisis are manifold. And the existence of elements of the crisis situation is observed in a long time. There are quite a lot of assessment criteria of role each factors. However their objectivity and real impact still are under discussion by experts. Then the problem becomes multifactorial, multidimensional and, ultimately, indefinite. Therefore, the expert method was applied to evaluate the role of each factor.

The experts were randomly selected from 246 professional managers. The experts were asked to rate each factor at three time points. The factors were tabulated, that was obtained as follows. The list of factors of research consulting firm McKinsey in 1999 and 2009, and other resources have been selected as the base. Accordingly, 1999, 2009 and the current 2012 were chosen as time points. Results of the surveys thus obtained are presented in Table 1. 
Table 1. Factors that affect to development of the crisis in Russia

\begin{tabular}{|c|c|c|c|c|}
\hline № & Name of indicator & $\begin{array}{l}\text { Level of } \\
\text { influence in } \\
1999\end{array}$ & $\begin{array}{l}\text { Level of } \\
\text { influence in } \\
2009\end{array}$ & $\begin{array}{l}\text { Level of } \\
\text { influence in } \\
2012\end{array}$ \\
\hline 1 & Low productivity of labor & 53,3 & 51,7 & 52,5 \\
\hline 2 & Excess or lack of manpower & 56,7 & 42,5 & 45 \\
\hline 3 & Inefficient organization of enterprises activity & 50 & 51,7 & 50,8 \\
\hline 4 & Inequality of competition conditions & 46,7 & 483 & 55 \\
\hline 5 & $\begin{array}{l}\text { The impact of negative factors in the related } \\
\text { industries }\end{array}$ & 39 & 37 & 33 \\
\hline 6 & Macroeconomic instability within the country & 43,3 & 60 & 51,7 \\
\hline 7 & Problems in corporate governance & 42 & 46 & 38 \\
\hline 8 & Restriction of labor mobility & 50 & 46,7 & 46,7 \\
\hline 9 & The weakness of the judicial system & 53,3 & 55,8 & 56,7 \\
\hline 10 & $\begin{array}{l}\text { Mistrust of banks, and the underdevelopment of } \\
\text { the financial system }\end{array}$ & 44,2 & 41,7 & 36,7 \\
\hline 11 & Backwardness of transport infrastructure & 53,3 & 46,7 & 50 \\
\hline 12 & The possibility of social unrest & 44,2 & 40,8 & 50 \\
\hline 13 & Corruption & 73,3 & 75,8 & 79,2 \\
\hline 14 & $\begin{array}{l}\text { The lack of economic information and } \\
\text { knowledge }\end{array}$ & 56,7 & 62,8 & 50,8 \\
\hline 15 & Antisocial directivity of economic policies & 41,7 & 41,7 & 42,5 \\
\hline $16 * *$ & Unfavorable investment climate & 56,7 & 66,7 & 68,3 \\
\hline $17 * *$ & $\begin{array}{l}\text { Large difference in income and significant social } \\
\text { differentiation }\end{array}$ & 45 & 51,7 & 62,5 \\
\hline $18 * *$ & Low innovation potential of the economy & 50 & 60 & 55,8 \\
\hline $19 * *$ & Crisis of the education system & 56,7 & 65,8 & 71,7 \\
\hline $20 * *$ & Crisis of the health care system & 46,7 & 48,3 & 49,2 \\
\hline $21 * *$ & Monopolization of the economy & 41,7 & 63,3 & 70 \\
\hline $22 * *$ & $\begin{array}{l}\text { Lack of small and medium businesses } \\
\text { development }\end{array}$ & 55 & 56,7 & 56,7 \\
\hline $23 * *$ & Hasty and inefficient privatization & 49,2 & 45,8 & 44,2 \\
\hline $24 * * *$ & Complex demographic situation & 50 & 50,8 & 50 \\
\hline $25 * * *$ & $\begin{array}{l}\text { Problems regional development and the absence } \\
\text { of their comprehensive solution }\end{array}$ & 60 & 56,7 & 56,7 \\
\hline $26 * * *$ & Low efficiency of public administration & 80,8 & 79,2 & 74,2 \\
\hline $27 * * *$ & Raw material orientation & 67,5 & 69,2 & 65,8 \\
\hline $28 * * *$ & Unpredictability of state economic policy & 51,7 & 40,7 & 34,2 \\
\hline $29 * * *$ & Inflation & 49,2 & 40 & 40,8 \\
\hline $30 * * *$ & The high cost of attracting financial resources & 41,7 & 53,3 & 60 \\
\hline $31 * * * *$ & Inefficient organization of labor & 56,7 & 56,7 & 55,8 \\
\hline $32 * * * *$ & Outdated equipment and inefficient technologies & 65 & 55 & 58,3 \\
\hline $33 * * * *$ & The structural problems of the Russian economy & 60 & 56,7 & 60 \\
\hline $34 * * * *$ & $\begin{array}{l}\text { Opaque and over-regulation of business } \\
\text { processes }\end{array}$ & 53,3 & 52,5 & 53,3 \\
\hline $35 * * * *$ & $\begin{array}{l}\text { Conservatism in the socio-economic } \\
\text { transformation }\end{array}$ & 53,3 & 51,7 & 58,3 \\
\hline
\end{tabular}

* Russian economy: growth is possible. Study of the performance of key industries. McKinseyGlobalInstitute, 1999.,

** Suvorov N.A. Ekonomika: A Handbook for the Study of the discipline in section "Economic growth". M. MGTY GA, 2007, 36 p.

*** Abramov A.Y. and other. Scientific ed. Gaidar ET Crisis Economics modern Russia. Trends and prospects. M.: Prospect, 2010, 654 p.

**** Effective Russia: Performance as the foundation of growth. McKinseyGlobalInstitute, 2009. 


\section{Discussion}

As the data in Table 1 the following factors have been most significant for inhibition of the Russian economy from the full list of factors that was rated by expert-managers. These factors are listed below in descending order of importance. Corruption appeared the most important restraining force in the first group of the most influencing factors. Inefficient public administration, the crisis of the education system, and the monopolization of the economy enter into this subgroup well. Unfavorable investment climate, raw materials orientation, high income gap and significant social differentiation are in the second group less influencing factors. Furthermore, the high cost of raising financial resources and the structural problems of the Russian economy are included there. Remaining factors can be attributed to the groups with medium and weak impact.

Attention is drawn to the fact that the significance of almost all factors the first group increases. But the influence of the ineffectiveness of government is reduced. "Addiction" of citizens and organizations toward this fact helps to explain the last effect. The finding "of detours", e.g. by the same corruption is the next step. An effect of inefficient public administration and the influence unpredictable of government economic policy falling down. Obviously, this is caused by the same factors that the falling down the influence of ineffective privatization.

However, the conservatism of economic policy and the desire to preserve status quo, probably are the most important. This can be seen from the fact that significant factors in 1999 remain such with almost no changes to the 2009 study, as well as three years later.

Russia's economy is based on outdated industrial principles and imperfect technology.60-65 percent of the production capacities frayed. Commercialize innovative projects represent less than 1 percent of the total. Therefore, the domestic economy is clumsy and cannot follow the trends on the world market. Accordingly, the Russian companies can offer the world market is less and less competitive products. As a result, Russia's share in world trade is small, and it is disproportionately of its role in global economic. The growth of this share is associated mainly with the export of petroleum products, crude oil and natural gas.

Such backlog from the leading world powers leads to numerous negative consequences. Including it is linked to the understanding of the situation for many Russian citizens. Monitoring and evaluation of the author allowed define the share of people such as at least 47 percent. Such social and psychological factors, as apathy and low efficiency of labor, can be called the most important consequences of the pre-crisis of stagnation in the Russian economy. People embittered and they do not see any prospects. According to the data by VCIOM, only 42 percent of Russians evaluates the immediate future of the domestic economy as favorable .41 percent of respondents, vice versa, expect the negative. According to 37 percent of Russians, hard times still awaiting Russia. Social tensions and reduced intellectual level of the society are a consequence.

The fall of human development indicators is not as obvious as a slowdown in in GDP growth. It occurs in the form of a slowdown in growth, even according to official sources (Davydov A.A. Human Development in Russia: long-term prognosis. Sociological Research. 2011, № 7, p. 70-83.) and (Report on Human Development in the Russian Federation, 2011. Modernization and development of human potential. Moscow, 2011, 148 p.), as can be seen from the graph in Fig.4a.In addition to the official data should use the results of independent studies (Prediction of the Human Development Index (HDI). Website "Sociology". http://www.sociolesson.ru/socless-987-2.html.), (Radzikhovskiy L. Comparison of potential of the individuum (HDI) in Russia and the world. Site "Free access to educational software». http://viperson.ru/wind.php?ID=655605\&soch=1.). As a result, it can be concluded that, for the last dozen years of growth of the index of human development there is little, as can be seen from the graph of Figure $4 \mathrm{~b}$. This is not consistent with a high proportion of young people and the educated urban population that also indicates to crisis.
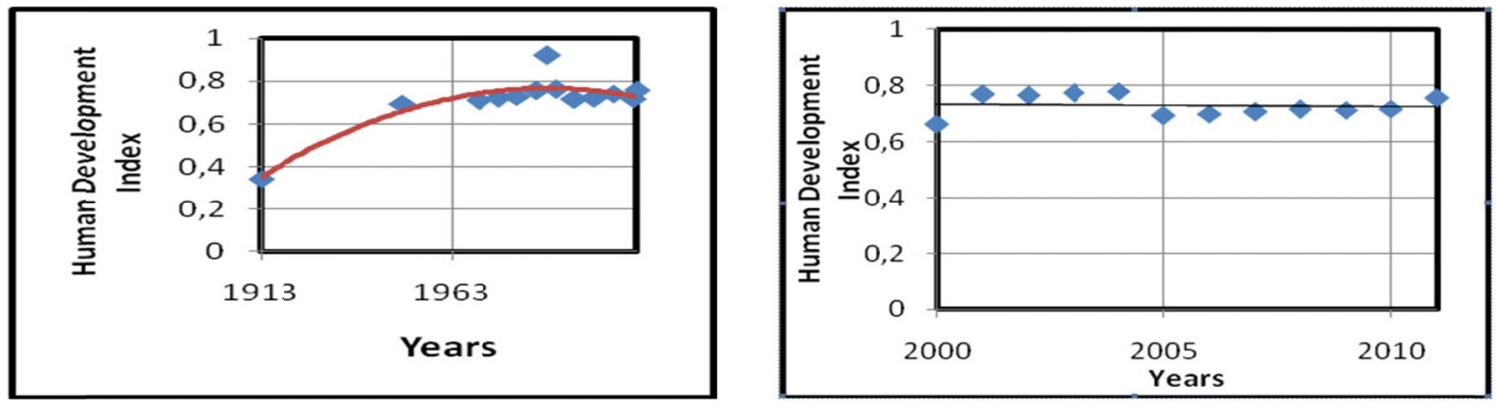

Figure 4a. Change in the index of human development by the years according to official figures and $4 \mathrm{~b}$. Based on the data of independent studies 
Particularly notable looks the abatement rate of economic growth and human development outcomes, with increasing proportion of young people in Russia. According to the statistical collection of "Youth in Russia - 2010" the total number of young people in Russia has increased from 31 million in 1995 up to 33 million people in 2009 . In 2012 the number of young people is 39.6 million people, representing 27 percent of the total population. The urban population in 2010 was 73.7 percent. Thus, a high proportion of young active population, and the urban population has a higher level of education. It is important for the promotion of post-industrial economy. It provides the highest profitability, and therefore, can help to ensure high rates of economic growth in today's situation in Russia.

A high demand for IT-professionals shows that the post-industrial stage is on approach. The source (Logvinov M. Staff in IT-sphera are everything. Portal CNews. Analytics. http://www.cnews.ru/reviews/free/itservice2011/articles/articles19.shtml.) says that the Russian ICT market is developing very actively. However, according to experts, the shortage of qualified specialists could seriously hinder this development. This is evidenced by at least the level of proposed salaries for IT-specialists. According to the source (IT personnel: knowledge of deficient things are in price. Cnews, 2012, № 63, c.90-91.), for the first half of 2012 salaries in the IT-sector grew by 6.9 percent. It is 2 times higher than the market average. Total growth of vacancies in IT-sector was 26 percent.

However, the development of modern industrial and post-industrial technology cannot be stopped. In combination with the demographic characteristics of modern Russia in the crisis, this situation causes social tensions. It shows up first of all, in the growing number of strikes. According to the research Center of social and labor rights in the first quarter of 2012 was the largest in the last five years. 61 incidents of an open manifestations aspirations of workers to defend their rights was registered. This organization monitors such events based on open sources, including the media and the Internet. According to their data you can build a graph Figure 5, of which could see steady growth of the strike movement in Russia.

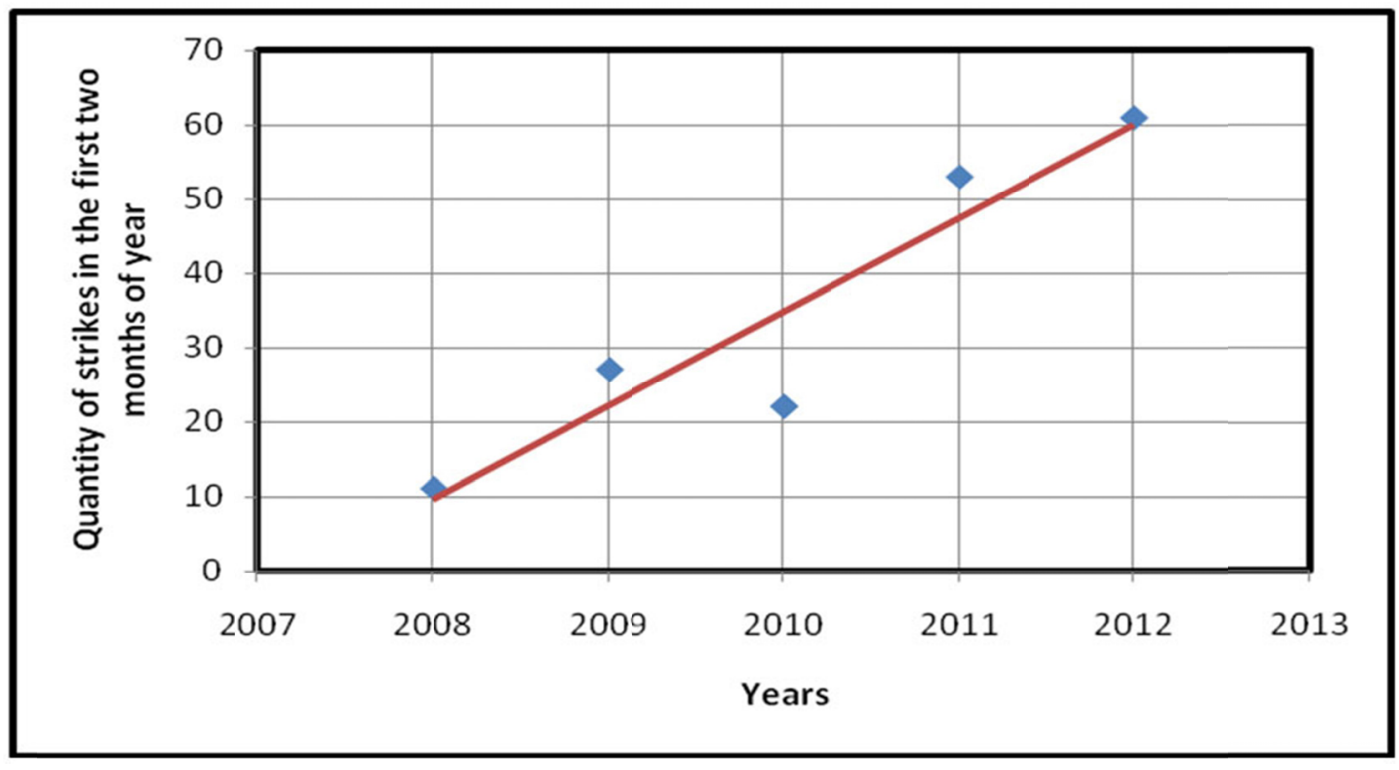

Figure 5. The growth of the strike movement in Russia in the first two months of each year by years

Center for Social and Labor Rights predict growth of strikes in Russia up to 40-45 per month.The last and enough significant event of this kind was the strike at the Ford plant in Vsevolozhsk, Leningrad region, which the plant management in every way tried to hide.

\section{Conclusion}

However, the potential of the Russian society and its economy is large, and it can be implemented into concrete achievements provided the correct formulation of the case. High rate of profit on investment, which, for obvious reasons, investors prefer not to indicate, says about the same. The crisis of Western economies is inexorably approaching. It induces phenomena of crisis in the Russian economic sphere, what leads to the clearly predictable negative post-crisis implications. However, investments in Russia can be very profitable. This can occur under certain conditions, despite the unavoidable risks. 


\section{References}

$41 \%$ of Russians are pessimistic about the economy. Website Rosinvest.com. Retrieved November 12, 2012, from http://rosinvest.com/novosti/1001800

Abramov A.Y. and other. Scientific ed. (2010). Gaidar ET Crisis Economics modern Russia. Trends and prospects. M.: Prospect, p. 654.

Central Bank has estimated the outflow of capital from Russia in the first quarter. Website Meta.kz. Retrieved April 4, 2012 , from http://www.meta.kz/novosti/economy/658454-cb-podschital-ottok-kapitala-iz-rossii-v-pervom-kvartale.html

Chichkin A. Worn out. The level of depreciation of fixed assets in Russia is much higher than in the other BRICS countries. "Rossiyskaya Gazeta" - Economy "Modernization», № 5519 (143). 05.07.2011.

Davydov A.A. (2011). Human Development in Russia: long-term prognosis. Sociological Research, 7, 70-83.

Effective Russia: Performance as the foundation of growth. McKinseyGlobalInstitute, 2009.

Glukhova M.V. Gross regional product and the practice of its calculation in Russia. Retrieved from http://www.cisstat.com/meet-sna2004/glukhova.htm

Gross domestic product and gross value added by economic activity Rosstat. Retrieved from http://yandex.ru/clck/jsredir?from=yandex.ru\%3Byandsearch $\% 3 \mathrm{Bweb} \% 3 \mathrm{~B} \% 3 \mathrm{~B} \&$ text $=\% \mathrm{D} 0 \% 92 \% \mathrm{D} 0 \% \mathrm{~B} 0 \% \mathrm{D}$ 0\%BB $\%$ D0\%BE\%D0\%B2\%D0\%BE\%D0\%B9\%20\%D0\%B2\%D0\%BD\%D1\%83\%D1\%82\%D1\%80\%D0\%B5 $\% \mathrm{D} 0 \% \mathrm{BD} \% \mathrm{D} 0 \% \mathrm{BD} \% \mathrm{D} 0 \% \mathrm{~B} 8 \% \mathrm{D} 0 \% \mathrm{~B} 9 \% 20 \% \mathrm{D} 0 \% \mathrm{BF} \% \mathrm{D} 1 \% 80 \% \mathrm{D} 0 \% \mathrm{BE} \% \mathrm{D} 0 \% \mathrm{~B} 4 \% \mathrm{D} 1 \% 83 \% \mathrm{D} 0 \% \mathrm{BA} \% \mathrm{D} 1$ $\% 82 \% 20 \% \mathrm{D} 0 \% \mathrm{~B} 8 \% 20 \% \mathrm{D} 0 \% \mathrm{~B} 2 \% \mathrm{D} 0 \% \mathrm{~B} 0 \% \mathrm{D} 0 \% \mathrm{BB} \% \mathrm{D} 0 \% \mathrm{BE} \% \mathrm{D} 0 \% \mathrm{~B} 2 \% \mathrm{D} 0 \% \mathrm{~B} 0 \% \mathrm{D} 1 \% 8 \mathrm{~F} \% 20 \% \mathrm{D} 0 \% \mathrm{~B} 4 \%$ D0\%BE\%D0\%B1\%D0\%B0\%D0\%B2\%D0\%BB\%D0\%B5\%D0\%BD\%D0\%BD\%D0\%B0\%D1\%8F\%20\%D1 $\% 81 \% \mathrm{D} 1 \% 82 \% \mathrm{D} 0 \% \mathrm{BE} \% \mathrm{D} 0 \% \mathrm{~B} 8 \% \mathrm{D} 0 \% \mathrm{BC} \% \mathrm{D} 0 \% \mathrm{BE} \% \mathrm{D} 1 \% 81 \% \mathrm{D} 1 \% 82 \% \mathrm{D} 1 \% 8 \mathrm{C} \% 20 \% \mathrm{D} 0 \% \mathrm{BF} \% \mathrm{D} 0 \% \mathrm{BE}$ $\% 20 \% \mathrm{D} 0 \% \mathrm{~B} 2 \% \mathrm{D} 0 \% \mathrm{~B} 8 \% \mathrm{D} 0 \% \mathrm{~B} 4 \% \mathrm{D} 0 \% \mathrm{~B} 0 \% \mathrm{D} 0 \% \mathrm{BC} \% 20 \% \mathrm{D} 1 \% 8 \mathrm{D} \% \mathrm{D} 0 \% \mathrm{BA} \% \mathrm{D} 0 \% \mathrm{BE} \% \mathrm{D} 0 \% \mathrm{BD} \% \mathrm{D} 0 \% \mathrm{~B}$ E\%D0\%BC\%D0\%B8\%D1\%87\%D0\%B5\%D1\%81\%D0\%BA\%D0\%BE\%D0\%B9\%20\%D0\%B4\%D0\%B5\%D $1 \% 8 \mathrm{~F} \% \mathrm{D} 1 \% 82 \% \mathrm{D} 0 \% \mathrm{~B} 5 \% \mathrm{D} 0 \% \mathrm{BB} \% \mathrm{D} 1 \% 8 \mathrm{C} \% \mathrm{D} 0 \% \mathrm{BD} \% \mathrm{D} 0 \% \mathrm{BE} \% \mathrm{D} 1 \% 81 \% \mathrm{D} 1 \% 82 \% \mathrm{D} 0 \% \mathrm{~B} 8 \% 20 \% 2 \mathrm{~F} \% 2 \mathrm{~F}$ $\% 20 \% \mathrm{D} 0 \% \mathrm{~A} 0 \% \mathrm{D} 0 \% \mathrm{BE} \% \mathrm{D} 1 \% 81 \% \mathrm{D} 1 \% 81 \% \mathrm{D} 1 \% 82 \% \mathrm{D} 0 \% \mathrm{~B} 0 \% \mathrm{D} 1 \% 82 . \&$ uuid=\&state=AiuY0DBWFJ4ePaE se6rgeKdnI0e4oXuRYo0IEhrXr7zk7-LazHAr5Rwrl5F4jVTbrsUYBFoENSLM13X2a5e1lsx2Wujr0Whs_hGV uIydkefNq3y9STK1x9Sz3AhsdSc4NMV0A1kDiuoMLfPMBJ8bKfnCF2Dbm2VMvfl8yugd1S9OdTlkd6mh7x aunecr7gJApkUn4IEaU2Q\&data=UlNrNmk5WktYejR0eWJFYk1Ldmtxcm9STWtXdDRmOTd2Q2plZ1JmTz BFdINlcGNoRnRWN1dwREFISXd6Y1BGY31wOFNHWVY2UU1FR3VObUxoWkVUYXBROGx3M0VyRE wySjZUUHhCSmRHR21acWV5NWpIMjAyeW53cFBXajhGaWNCM0ZEeE5vU1ZtR3JFbi1kQWtXMDFn\& $\mathrm{b} 64 \mathrm{e}=2 \& \operatorname{sign}=2 \mathrm{ad} 59566 \mathrm{~b} 0 \mathrm{~b} 6 \mathrm{aca} 63 \mathrm{~d} 20 \mathrm{faed} 26835 \mathrm{a} 9 \mathrm{~b} \& \mathrm{keyno}=0 \& 110 \mathrm{n}=\mathrm{ru} \& \mathrm{mc}=4.708758439731455$

Gutorova M. Chapter of the Institute of Economic Research: "Russia can not avoid the consequences of the crisis." Arguments and Facts. Retrieved October 22, 2012, from http://www.aif.ru/money/article/56325/3

IMF downgraded the outlook for GDP growth in Russia for 2012-2013. Rossiyskaya gazeta.09.10.2012.

IT personnel: knowledge of deficient things are in price. Cnews, 2012, № 63, c.90-91.

Kornukhin V. Kazakhstan - the investment leader postsoviet space? Gross domestic product (GDP) of Russia, 1990-2010. Comparing GDP of Russia and neighboring countries. The Website «The first trustee». Retrieved from http://vip.1-du.ru/news/681454/

Kuskova I.M., \& Urzha O.A. (2007). Formation of youth policies at the municipal level. Journal of scientific publications graduate and doctoral students, 11 .

Logvinov M. Staff in IT-sphera are everything. Portal CNews. Analytics. Retrieved from http://www.cnews.ru/reviews/free/itservice2011/articles/articles19.shtml.

Maligin L. (2011). Puzzle efficiency. Expert-Ural, № 12 (459). March 28.

Mironov V. The Russian economy is seriously ill. To save her, one must do the impossible. Website MKRU. Retrieved from http://www.mk.ru/economics/article/2012/10/31/768612-rossiyskaya-ekonomika-serezno-bolna.html

Portnov A.M. "Simple Product" Russia. Independent online newspaper Communar press. Retrieved May 17, 2012, from http://kommunar-press.ru/component/option,_com_frontpage/Itemid,1/limit,7/limitstart,763/

Prediction of the Human Development Index (HDI). Website "Sociology". Retrieved from $\mathrm{http}: / /$ www.sociolesson.ru/socless-987-2.html 
Press agency FCO. Over the decade, growth of Russia's GDP was 159.2\% - calculation of the FCO. Retrieved from http://www.cfin.ru/base/shownewsrelease.php3?ID=16007

Radzikhovskiy L. Comparison of potential of the individuum (HDI) in Russia and the world. Site "Free access to educational software». Retrieved from http://viperson.ru/wind.php?ID=655605\&soch=1

Report on Human Development in the Russian Federation. (2011). Modernization and development of human potential. Moscow, p.148.

Russia completed 2011 with a budget surplus in 416,500,000,000,000. rubles. The Website agency "Rosbalt". Retrieved from http://www.rosbalt.ru/business/2012 / 01/19/934972.html/

Russia has increased its share in world trade. Agency advice and business information "ACDI Business and Life." Retrieved October 25, 2010 from http://www.akdi.ru/scripts/novosti/smotri.php?z=10444

Russian economy: growth is possible. Study of the performance of key industries. McKinseyGlobalInstitute, 1999.

Salaries of IT professionals in Moscow is near to the level of Europe. Portal "SmartSorsing. Community managers of IT companies, IT departments and service centers». Retrieved from http://smartsourcing.ru/blogs/svobodnoe_mnenie/1355

St. Petersburg plant Ford stopped the conveyor. At the Petersburg plant Ford took a sudden change. Informational and educational portal WorkPulse.ru. $\quad$ Retrieved from http://diyhelp.ru/pluse-business/na-piterskom-zavode-ford-proizoshli-vnezapnye-izmeneniya.html

Surinov A. (2011). What we think we are. Rosstat summarized the census. Russian newspaper. Federal issue number 5440(64), March 28.

Suvorov N.A. Ekonomika: A Handbook for the Study of the discipline in section "Economic growth". M. MGTY GA, 2007, p.36.

The strike in Russia is becoming the norm. Website Vyborg Gazette. Retrieved April 20, 2012, from http://vyborg-press.ru/sblogs/today_russia/2012/04/20/zabastovka_v_rossii_stanovitsya_normoiy

Website of the Federal State Statistics Service. Retrieved from http://www.gks.ru/

Youth in Russia. (2010). Statistical Compendium. Moscow: Publishing Center "Statistics of Russia", p.167.

Zubchenko E. (2012). Covers the second wave of the crisis. Economist Igor Nikolaev. Novye Izvestia, 05.06. 